\title{
Pelatihan Penggunaan Aplikasi Data Bahan Kimia Pada Smk Taruna Persada Dumai (Jurusan Laboratorium Kimia Smk Taruna Persada)
}

\author{
Desyanti $^{* 1}$, Susy Sri Handayani ${ }^{2}$, Wetri Febrina, Febrina Sari ${ }^{4}$ \\ ${ }^{1}$ Program Studi Teknik Informatika, Sekolah Tinggi Teknologi (STT) Dumai \\ 2Program Studi TekniK Sipil, Sekolah Tinggi Teknologi (STT) Dumai \\ ${ }^{3}$ Program Studi Teknik Industri, Sekolah Tinggi Teknologi (STT) Dumai \\ *e-mail: desyanti734@gmail.com,gadisoil79@gmail.com,wetri.febrina@gmail.com, \\ febri_ghaniya@yahoo.co.id
}

\begin{abstract}
SMK Taruna Persada Dumai has thirteen (13) majors, one of which is Chemical Engineering. This department has several practical subjects using chemicals. For each practicum students must write on a piece of paper the chemicals that will be used and then submitted to the admin section, the admin will look for one by one type of chemical on the chemical shelf. There are almost 100 types of chemicals in the chemical laboratory of Taruna Persada Vocational School, because the chemicals are taken using paper filled by students during the practicum, it is not detected how many volumes and weights of each bottle are in the cupboard and the admin also doesn't know quickly when it will run out these chemicals. For this reason, the author makes a chemical stock application at the Taruna Persada Vocational School using PHP and MySQL, where the application contains information in the form of chemical data, the active period of the chemical, the number of chemical stocks in the laboratory, the purchase and use of chemicals. so that the admin can easily record the stock of chemicals that are still available.
\end{abstract}

Keywords: Applications, Chemicals, PHP and MySQL

\begin{abstract}
Abstrak
SMK Taruna Persada Dumai memiliki tiga belas (13) jurusan, salah satunya Teknik Kimia. Jurusan ini terdapat beberapa mata pelajaran praktikum menggunakan bahan - bahan kimia. Untuk setiap praktikum siswa harus menulis di selembar kertas bahan kimia yang akan digunakan kemudian diserahkan kebagian admin, admin akan mencari satu persatu jenis bahan kimia di rak bahan kimia. Terdapat hampir 100 jenis bahan kimia di laboratorium kimia SMK Taruna Persada, karena bahan kimia tersebut diambil menggunakan kertas yang diisi siswa saat praktikum maka tidak terdeteksi berapa jumlah volume dan berat dari setiap botol yang ada dilemari dan admin juga tidak mengetahui secara cepat kapan masa habis pakai bahan kimia tersebut. Untuk itu penulis membuat aplikasi stok bahan kimia pada SMK Taruna Persada menggunakan PHP dan MySQL, dimana pada aplikasi tersebut berisikan informasi berupa data - data bahan kimia, masa aktif dari bahan kimia, jumlah stok bahan kimia yang ada di Laboratorium,pembelian dan pemakain bahan kimia sehingga memudahkan admin dalam mendata stok bahan kimia yang masih ada.
\end{abstract}

Kata kunci: Aplikasi, Bahan Kimia, PHP dan MySQL

\section{PENDAHULUAN}

Sekolah Menengah Kejuruan (SMK) adalah salah satu jenjang pendidikan menengah dengan kekhususan mempersiapkan lulusannya untuk siap bekerja. SMK Taruna Persada Dumai adalah salah satu sekolah swasta di Kota Dumai yang berdiri sejak tahun 1997 yang memiliki 13 jurusan, diantaranya jurusan teknik mesin, jurusan teknik elektro, teknik informatika, teknik listrik, teknik kimia dan jurusan lainya. Pada Jurusan teknik kimia terdapat beberapa mata pelajaran yang mengharuskan siswa melakukan praktikum menggunakan bahan - bahan kimia. Untuk setiap praktikum siswa harus mengisi formulir permintaan bahan - bahan kimia yang akan digunakan untuk praktikum di selembar kertas yang kemudian diserahkan kebagian admin, setelah itu admin memberikan bahan - bahan kimia yang diminta dengan mencari 
satu persatu jenis bahan kimia dikarenakan belom adanya aplikasi data bahan kimia yang mendata letak dari bahan kimia tersebut. Terdapat hampir 100 jenis bahan kimia yang ada di laboratorium kimia SMK Taruna Persada, karena bahan kimia tersebut diambil menggunakan formulir yang diisi siswa saat praktikum maka tidak terdeteksi berapa jumlah volume dan berat dari setiap botol yang ada dilemari dan admin juga tidak mengetahui secara cepat kapan masa pakainya berakhir. Untuk itu penulis membuat aplikasi stok bahan kimia pada SMK Taruna Persada menggunakan PHP dan MySQL, dimana pada aplikasi tersebut berisikan informasi berupa data - data bahan kimia, masa aktif dari bahan kimia, jumlah stok bahan kimia yang ada di Laboratorium,pembelian dan pemakain bahan kimia sehingga admin dapat dengan mudah mendata stok bahan kimia yang masih ada.pada penelitian sebelumnya yang berjudul Pengelolaan Alat dan Laboratorium Kimia (Raharjo, 2017), Raharjo mengelompokan data bahan kimia berdasarkan penataan alat dan bahan yang dibagi kedalam 3 kategori peralatan yang cara pengoprasian dan perawatan nya sulit, sedang dan rendah. Kemudian Dahlia (2018) membuat suatu Aplikasi Pengelolaan Bahan Kimia Laboratorium Biologi , aplikasi ini dibangun menggunakan php dan MySql yang menghasilkan informasi bahan kimia yang digunakan dan sudah diuji tingkat kepuasaan penggunaannya berdasarkan efektivitas, efeisiensi dan kepuasaan pengguna sebesar 85,55 \% . Penggunaan php dan Mysql sudah banyak digunakan dibeberapa aplikasi seperti yang digunakan oleh lestari (2020) yaitu merancang aplikasi kartu keluarga berbasis web, aplikasi ini memudahkan aparatur pemerintahan dalam mengelolah data kependudukan dan kartu keluarga.

\section{METODE}

Metode pelaksanaan dalam Program Kemitraan Masyarakat yang tim pelaksana lakukan adalah sebagai berikut:

1. Studi Lapangan Ke Calon Mitra

Studi lapangan dilakukan oleh pengusul sebelum mengusulkan program kemitraan masyarakat, pengusul melakukan studi lapangan ke daerah calon mitra. Dalam melakukan studi ini pengusul menggunakan metode observasi dan wawancara terhadap Kepala Sekolah SMK Taruna Persada Dumai bapak Dr.Sugiarto, MM.

2. Melihat dan Menganalisa Permasalahan yang Ada

Setelah melakukan observasi dan wawancara kepada Kepala Sekolah dan ketua jurusan teknik kimia ibu Risdama S.Pd ditemukan beberapa permaslahan yang ada pada jurusan tersebut, yaitu dalam proses permintaan bahan kimia untuk praktium siswa admin masih harus mencari jenis bahan kimia yang dibutuhkan satu persatu dikarenakan belum adanya aplikasi yang menyediakan informasi jumlah bahan kimia yang tersedia.

3. Solusi yang Ditawarkan

Solusi yang ditawarkan dalam Program Kemitraan Masyarakat ini adalah merancang Aplikasi data bahan kimia berbasis Unified Modeling Language (UML).

UML merupakan bahasa visual yang menjadi standar untuk menspesifikasikan, menggambarkan, membangun, dan dokumentasi dari sistem perangkat lunak (A.S, 2011). Selain itu penulis juga menggunakan Alat bantu perancangan sistem lainya berupa Hardware dan Software.

Hardware merupakan komponan fisik yang digunakan untuk aktivitas input, proses, output, dan penyimpanan pada suatu sistem komputer (Kusrini, 2007). Komponen hardware terdiri dari Laptop Tosiba Satellite L745 Core(TM) i3, Hardisk 500 GB, RAM 
2,00 GB dan Printer Epson L360 series sedangkan untuk software yang digunakan adalah :

a. Adobe Dreamweaver CS5

Adobe Dreamweaver CS5 merupakan software aplikasi yang digunakan sebagai HTML editor profesional untuk mendesain web secara visual. Aplikasi ini juga yang biasa dikenal dengan istilah WYSIWYG (What You See Is What You Get), yang intinya adalah bahwa pengguna tidak harus berurusan dengan tag-tag HTML untuk membuat sebuah situs. Selain itu, Dreamweaver jug a memberikan keleluasaan kepada pengguna untuk menggunakannya sebagai media penulisan bahasa pemrograman web. Sedangkan kemampuan Adobe Dreamweaver CS3 untuk berinteraksi dengan beberapa bahasa pemrograman seperti PHP, ASP, Java Script, dan yang lainnya juga memberikan fasilitas maksimal kepada para desainer web yang menyertakan bahasa pemrograman web di dalamnya (Winarno, 2012).

b. Hyper Text Markup Language (HTML)

Hypertext Markup Language (HTML) merupakan bahasa yang digunakan untuk menulis halaman web. HTML merupakan pengembangan dari standar pemformatan dokumen teks yaitu Standart Generalized Markup Language (SGML). HTML sebenarnya merupakan dokumen atau teks biasa, yang dirancang untuk tidak tergantung pada suatu sistem operasi tertentu. Perintah-perintah HTML diletakkan dalam file berekstensi *.html dan ditandai dengan mempergunakan tag (tanda) berupa karakter " < " dan " > ". Tidak seperti bahasa pemrograman berstruktur seperti pascal atau C, HTML tidak mengenal jumping atau looping. Kode-kode HTML dibaca oleh browser dari atas kebawah tanpa adanya lompatan-lompatan (Winarno, 2012).

c. Page Hypertext Prepocessor (PHP)

Hypertext Preprocessor yaitu bahasa pemrograman web server-side yang bersifat open source. PHP merupakan script yang terintegrasi dengan HTML dan berada pada server (server side HTML embedded scripting). PHP adalah script yang digunakan untuk membuat halaman website yang dinamis. Dinamis berarti halaman yang akan ditampilkan dibuat saat halaman itu diminta oleh client. Mekanisme ini menyebabkan informasi yang diterima client selalu yang terbaru/up to date. Semua script PHP dieksekusi pada server dimana script tersebut dijalankan (Anhar, 2010 ).

d. Database

Data Base atau yang sering disebut dengan basis data adalah kumpulan data yang saling berelasi. Data sendiri merupakan fakta mengenai objek, orang, dan lain-lain. Data dinyatakan dengan nilai (angka, deretan karakter, atau simbol). Basis data dapat didefinisikan yaitu himpunan kelompok data yang saling berhubungan yang diorganisasi sedemikian rupa sehingga kelak dapat dimanfaatkan dengan cepat dan mudah (Kusrini, 2007).

e. $M y S Q L$

$M y S Q L$ merupakan sistem database yang banyak digunakan untuk pengembangan aplikasi web. Alasannya mungkin karena gratis, pengelolaan datanya sederhana, memiliki tingkat keamanan yang bagus, mudah diperoleh, dan lain-lain (Raharjo, 2012).

f. Xampp

Xampp merupakan paket $P H P$ dan $M y S Q L$ berbasis open source, yang dapat digunakan sebagai tool pembantu pengembangan aplikasi berbasis $P H P$. Xampp mengombinasikan beberapa paket perangkat lunak berbeda ke dalam satu paket (Riyanto, 2010).

4. Menetapkan Prosedur Kerja

Sebelum melaksanakan kegiatan perlu ditetapkan prosedur kerja dengan tujuan setiap kegiatan yang dilaksanakan terarah. Prosedur kerja diawali dengan menetapkan mitra kerja. Dalam hal ini mitra kerja akan diajak berdiskusi dan memberikan informasi yang dibutuhkan oleh tim pengusul, kemudian dilakukan 
penerapan dan penggunaan teknologi yang ada. Kegiatan ini direncanakan akan dilakukan selama sekitar delapan bulan.

5. Peran serta mitra dalam pelaksanaan program kemitraan masyarakat ini sangat diharapkan, karena mitra yang lebih memahami karakteristik, suasana praktikum dan kondisi yang ada di lapangan. Kelebihan dan kemampuan mitra bila digabungkan dengan teknologi yang ditawarkan diharapkan akan menghasilkan luaran yang optimal dalam proses pelaksanaan kegiatan. Mitra akan mendampingi tim pengusul dalam melaksanakan kegiatan dari awal kegiatan sampai selesai, memberikan seluruh informasi yang dibutuhkan oleh tim pengusul dan mitra dapat memberikan solusi dan kendala yang dihadapi di lapangan.

6. Luaran

Luaran yang dihasilkan adalah Aplikasi Data bahan kimia yang ada dilaboratorium jurusan teknik kimia SMK Taruna Persada sehingga memudahkan admin dalam mengelolah data bahan kimia dan mencari bahan kimia sesuai dengan yang dibutuhkan secara cepat serta mengetahui jumlah volume dari masing - masing bahan kimia yang ada. Penyimpanan bahan kimia memerlukan penanganan khusus seperti asam kuat dan basa kuat serta bahan yang mudah teroksidasi.

7. Evaluasi

Setelah aplikasi data bahan kimia selesai dirancang dan diimplemetasikan di jurusan Teknik Kimia SMK Taruna Persada Dumai akan dilakukan evalusi kegiatan oleh pihak Sekolah kepada pihak pengusul, jika masih ada perbaikan yang harus dikembangkan, maka pihak pengusul akan memperbaiki sesuai dengan permintaan dari mitra.

\section{HASIL DAN PEMBAHASAN}

Sebelum kegiatan berlangsung tim pengabdian melakukan pembentukan panitia kegiatan PKM dan mempersiapkan administrasi kegiatan seperti membeli ATK, surat menyurat dan lainnya. Kegiatan Pengabdian kepada masyarakat yang berjudul Pelatihan Penggunaan Aplikasi Data Bahan Kimia pada SMK Taruna Persada Dumai telah selesai dilaksanakan pada bulan mei 2021. Adapun hasil yang dicapai pada pengabdian ini adalah sebagai berikut:

Tabel 1. Hasil Pencapaian Pengabdian

\section{Persiapan}

\begin{tabular}{|c|c|c|c|}
\hline Langkah & \multicolumn{2}{|l|}{ Tujuan } & Hasil \\
\hline $\begin{array}{l}\text { Pembentukan } \\
\text { Kegiatan PKM }\end{array}$ & $\begin{array}{l}\text { Membuat } \\
\text { Kepanitiaan } \\
\text { Pembagian Tugas }\end{array}$ & $\begin{array}{r}\text { Struktur } \\
\text { dan }\end{array}$ & $\begin{array}{l}\text { Struktur Kepanitiaan } \\
\text { terdiri dari beberapa Dosen } \\
\text { dan Mahasiswa STT Dumai }\end{array}$ \\
\hline $\begin{array}{l}\text { Menyiapkan } \\
\text { Kegiatan }\end{array}$ & $\begin{array}{l}\text { Menyiapkan } \\
\text { Keperluan } \\
\text { berhubungan } \\
\text { Kegiatan PKM }\end{array}$ & $\begin{array}{r}\text { Segala } \\
\text { yang } \\
\text { dengan }\end{array}$ & $\begin{array}{lr}\text { Menyiapkan } & \text { Surat } \\
\text { Pengantar Kegiatan PKM, } \\
\text { membuat Desain } & \text { Aplikasi } \\
\text { Data Bahan Kimia, } \\
\text { Menyiapkan } \\
\text { Kegiatan }\end{array}$ \\
\hline $\begin{array}{l}\text { Pembuatan Aplikasi Data } \\
\text { Bahan Kimia dan Panduan }\end{array}$ & $\begin{array}{lc}\text { Membuat } & \text { Aplikas } \\
\text { Bahan } & \text { Kimia } \\
\text { dengan } & \text { Peral }\end{array}$ & $\begin{array}{r}\text { Data } \\
\text { sesuai } \\
\text { ncangan }\end{array}$ & $\begin{array}{l}\text { Aplikasi Data Bahan Kimia } \\
\text { dan Panduan Tata Cara }\end{array}$ \\
\hline
\end{tabular}


ABDINE: Jurnal Pengabdian Kepada Masyarakat Vol. 01, No. 01, Juni 2021, Hal. 26 - 33

p-ISSN 2798-2882, e-ISSN 2798-2890

Penggunaan Aplikasi

Desain

Pengunaan

Pelaksanaan

\begin{tabular}{|c|c|c|}
\hline Langkah & Tujuan & Hasil \\
\hline $\begin{array}{ll}\text { Pelaksanaan } & \text { Pelatihan }\end{array}$ & Memudahkan Admin dalam & mampu \\
\hline Penggunaan Aplikasi Data & mendata Bahan Kimia & menjalankan aplikasi data \\
\hline Bahan Kimia pada SMK & yang ada di Labolatorium & bahan kimia yang sudah \\
\hline Taruna Persada Dumai & $\begin{array}{lll}\text { SMK } & \text { Taruna } & \text { Persada } \\
\text { Dumai } & & \end{array}$ & dirancang. \\
\hline \multicolumn{3}{|c|}{ Penutup } \\
\hline Evaluasi Kegiatan & $\begin{array}{l}\text { Mengetahui hal - hal yang } \\
\text { belum sesuai dengan yang } \\
\text { diharapkan }\end{array}$ & $\begin{array}{l}\text { Saran untuk perbaikan } \\
\text { Kegiatan PKM Selanjutnya }\end{array}$ \\
\hline Laporan Kegiatan & $\begin{array}{l}\text { Melaporkan Kegiatan PKM } \\
\text { yang telah dilakukan }\end{array}$ & $\begin{array}{l}\text { Laporan Akhir Kegiatan } \\
\text { PKM }\end{array}$ \\
\hline
\end{tabular}

Kegiatan PKM ini dilaksanakan pada tanggal 28 mei 2021 yang dihadiri oleh 20 orang yang terdiri dari 3 Orang Dosen STT , 2 mahasiswa STT , 1 Kepala Sekolah SMK Taruna, 4 orang Guru dan 10 orang operator disetiap jurusan. Kegiatan PKM ini diisi dengan pemaparan dari ibu Desyanti, M.Kom tentang pengunaan Aplikasi data bahan kimia didepan para audient. Setelah selesai menjelaskan penggunaan aplikasi Data Bahan Kimia selanjutnya operator jurusan kimia didampingi langsung untuk menjalankan aplikasi sesuai dengan tata cara penggunaan nya.

Berikut ini tampilan aplikasi data bahan kimia SMK Taruna Persada Dumai

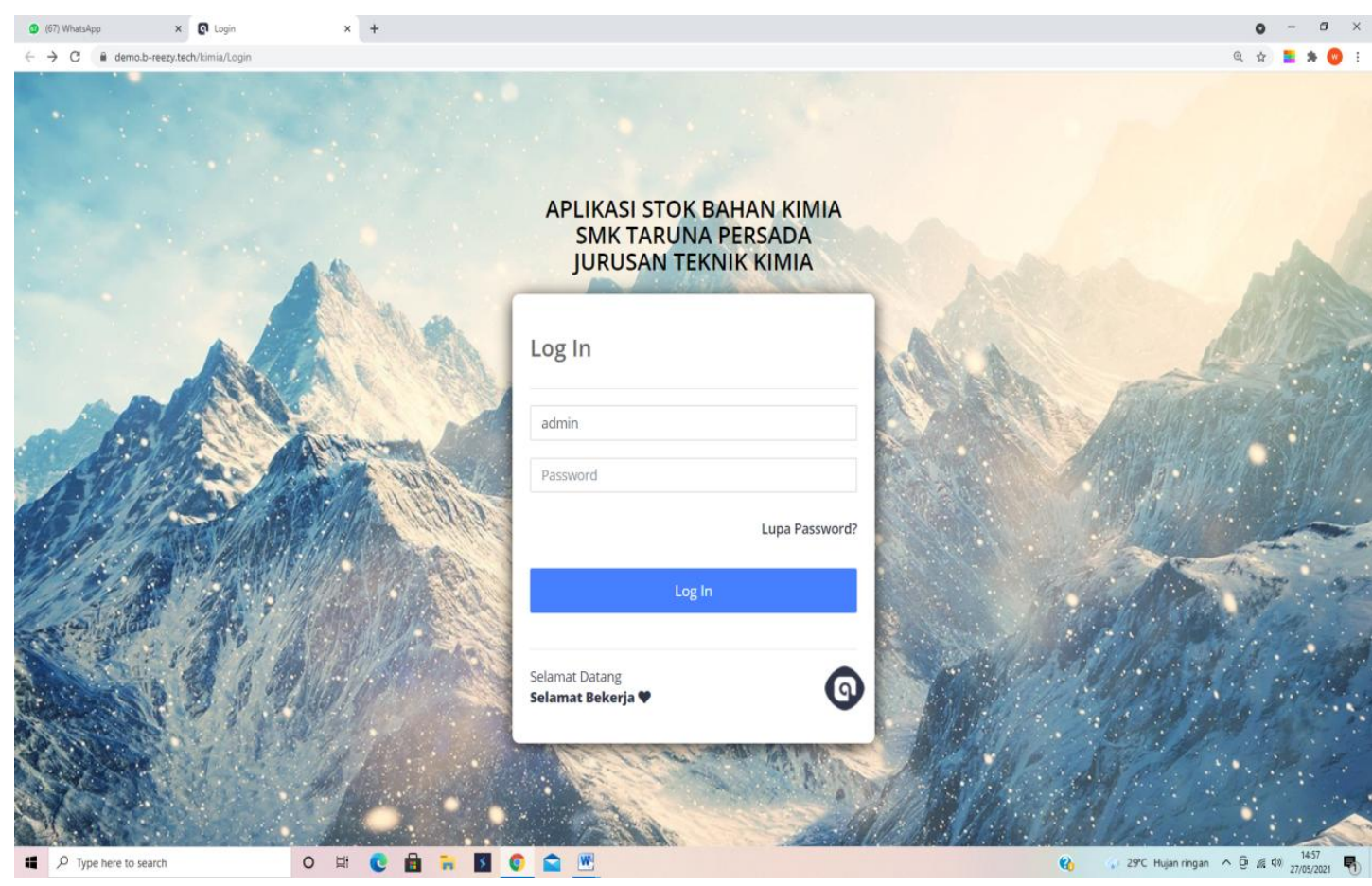

Gambar 1. Tampilan Menu Login Aplikasi Data Bahan Kimia

Setelah admin memasukan user dan passward yang benar maka akan tampil menu utama yang terdiri dari Menu Zat Kimia, Menu Pembelian dan Menu Pemakaian Data Bahan Kimia. 


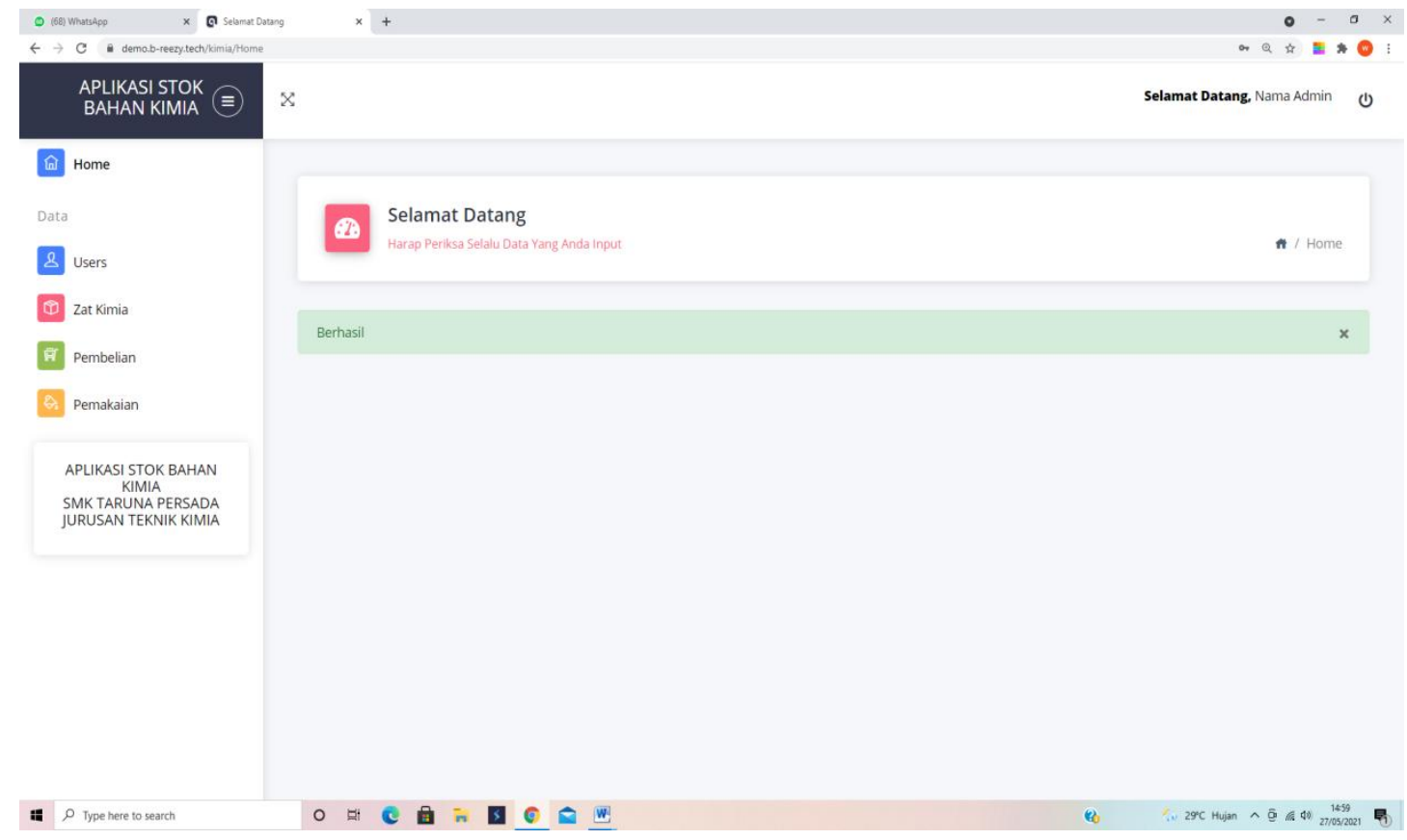

Gambar 2. Menu Utama Aplikasi Data Bahan Kimia

Setelah itu admin dapat melihat menu Data Zat Kimia dan menginputkan data bahan kimia sesuai dengan nama dan jenisnya, pada menu ini menampilkan Data Bahan Masuk, bahan terpakai dan sisa persediaan bahan kimia yang masih ada di labolatorium SMK Persada Dumai.

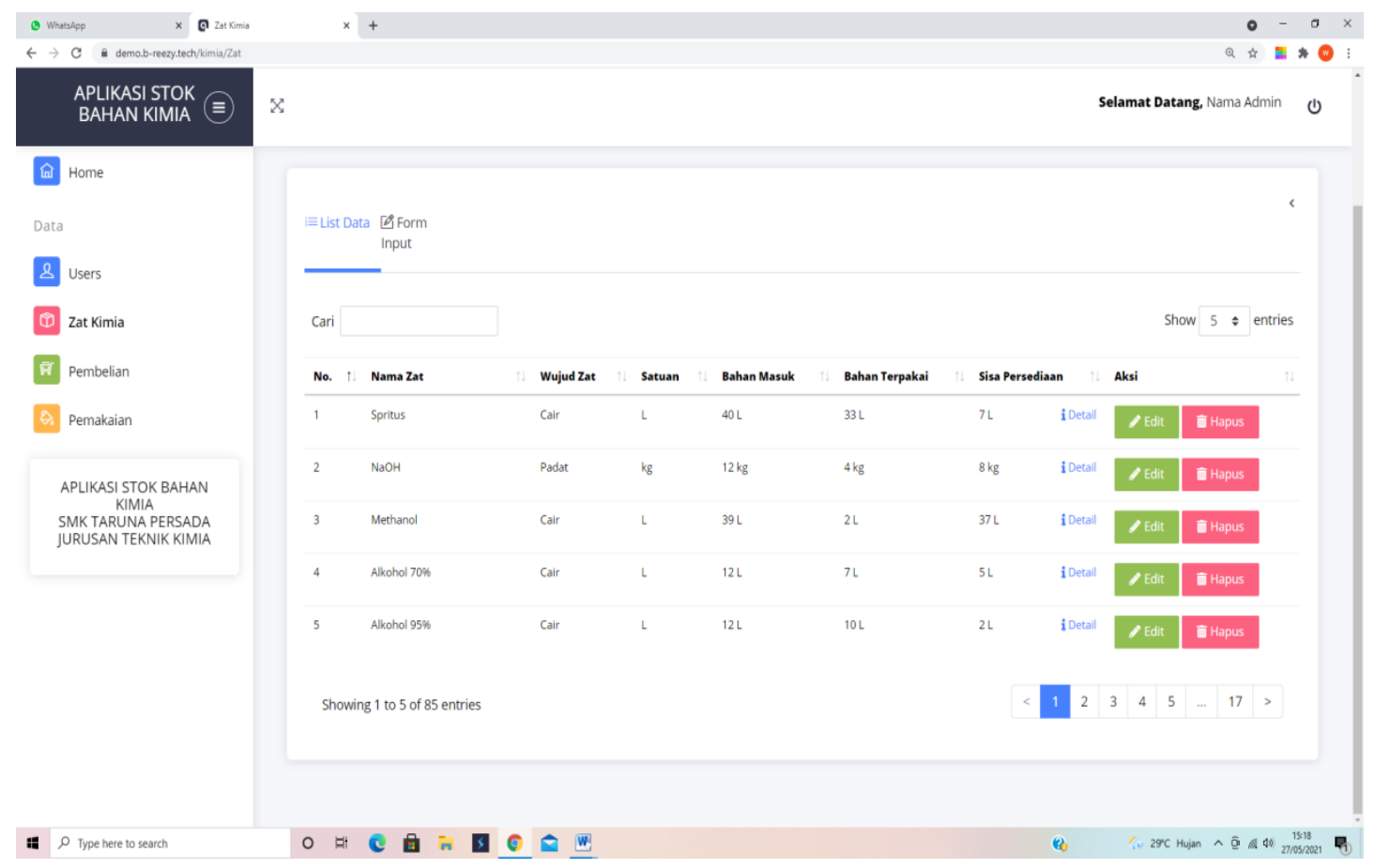

Gambar 3. Menu Zat Kimia pada Aplikasi Data Bahan Kimia 
Adapun proses pelaksanaan PKM dapat dilihat pada gambar 4 dan gambar 5

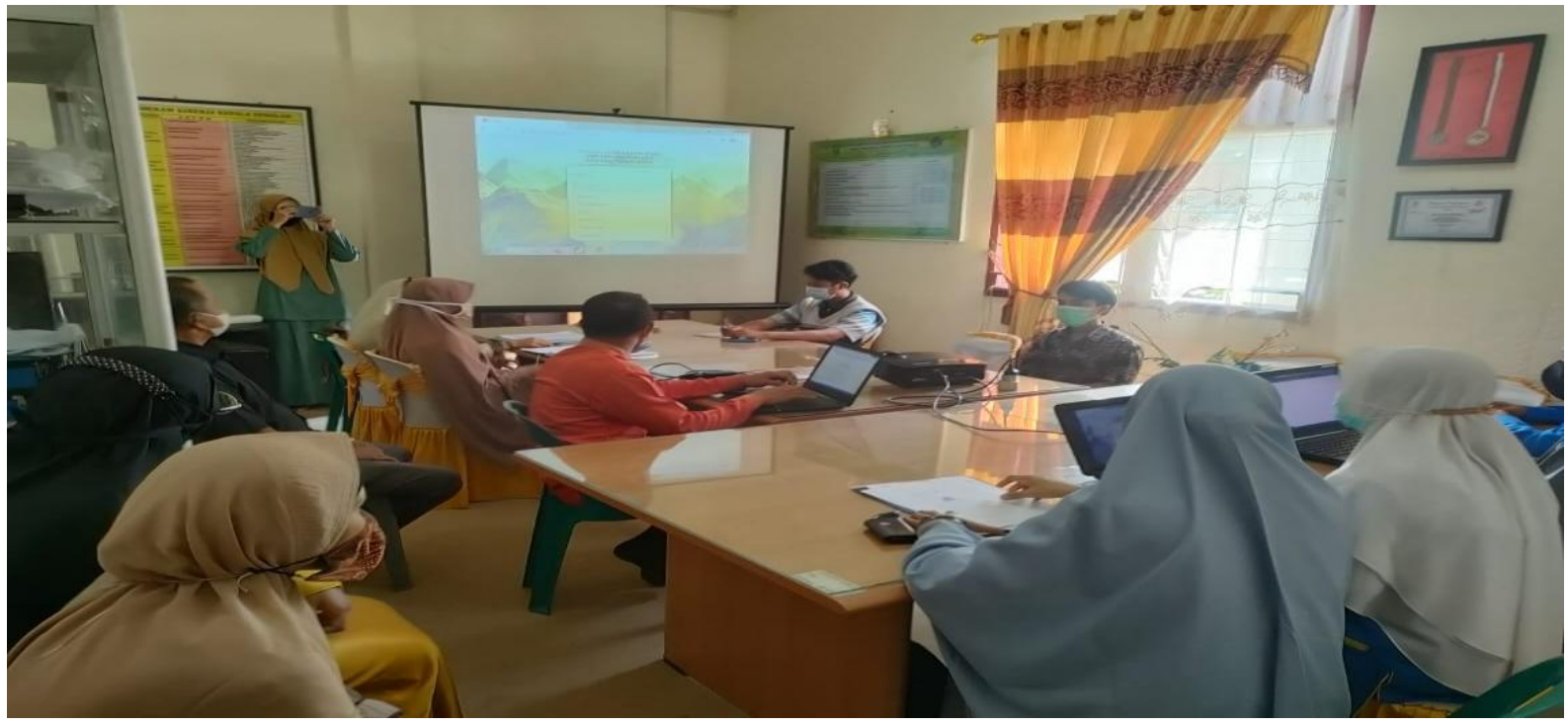

Gambar 4. Proses pemaparan penggunaan Aplikasi Data Bahan Kimia

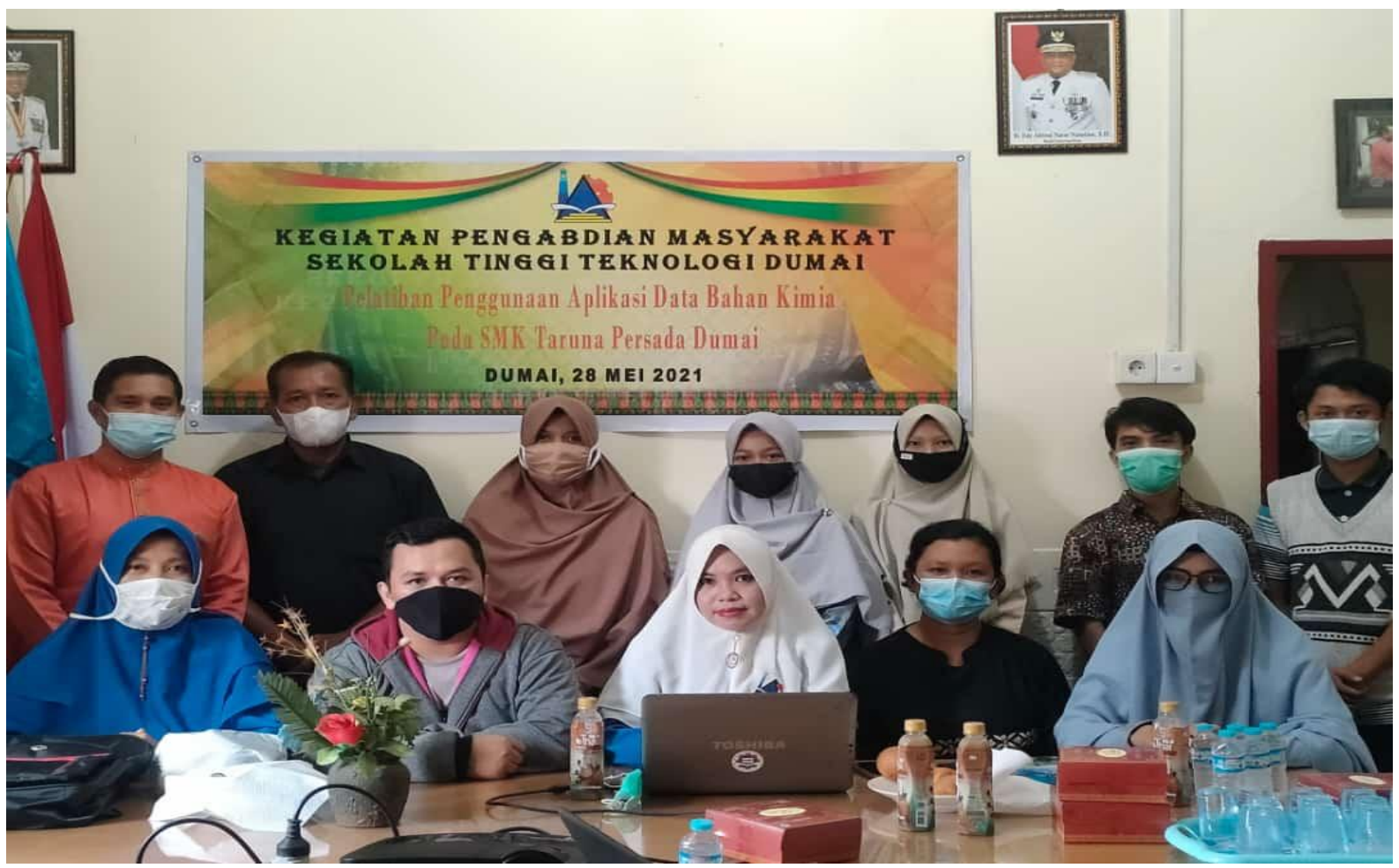

Gambar 5. Foto Bersama Peserta Kegiatan PKM.

Gambar 4 menunjukan proses pemaparan penggunaaan aplikasi oleh tim pengusul, yang dilanjutkan dengan tanya jawab oleh audient. Setelah proses kegiatan PKM selesai, tim PKM melakukan sesi foto bersama dengan guru2 dan admin SMK Taruna Persada Dumai.

\section{KESIMPULAN}

Dengan diadakan kegiatan pelatihan ini dapat memudahkan admin atau operator jurusan kimia dalam mendata bahan kimia yang ada di laboratorium SMK 
Taruna Persada Dumai sehingga proses pembelian zat kimia bisa disesuikan dengan jumlah stok yang ada.

\section{UCAPAN TERIMA KASIH}

Penulis mengucapkan terima kasih kepada Pimpinan Sekolah Tinggi Teknologi (STT) Dumai yang telah memberi dukungan financial terhadap pengabdian ini dan kepada kepala sekolah SMK Taruna Persada Dr. Sugiarto, MM dan ketua Jurusan Teknik Kimia yang telah memberikan waktu dan tempat untuk melaksanakan kegiatan PKM ini.

\section{DAFTAR PUSTAKA}

Anhar. (2010). Panduan Menguasai PHP \& MySQL Secara Otodidak, Mediakita, Jakarta.

A.S, Rosa., Shalahuddin, M., (2011). Modul Pembelajaran Rekayasa Perangkat Lunak, Modula, Bandung.

Dahlia Liza, dkk. (2018) Aplikasi Pengolahan Bahan Kimia Laboratorium Biologi FMIPA Universitas Tanjungpura. Jurnal sistem dan teknologi informasi vol 06 no 2 ISSN 2460- 3562.

Kusrini. (2007). Strategi Perancangan dan Pengelolaan Basis Data, Andi Offset, Yogyakarta.

Lestari Ninik Sri, Murti Dewi Sari Ratna. (2020). ISU Teknologi STT Mandala vol.15 No.02 p-ISSN 1979-4819 e-ISSN 2599 - 1930

Raharjo. (2017) Pengelolaan Alat dan Bahan dan Labolatorium Kimia. Jurnal Kimia Sains dan Aplikasi 20 (02) (2017): 99 - 104

Raharjo, B.( 2012). Modul Pemrograman WEB (HTML, PHP \& MySql). Modula, Bandung

Riyanto. (2010) XAMPP, Gava Media, Yogyakarta.

Winarno, Edy. (2012) Mobile Web Development dengan Dreamweaver. PT Elex Media Komputindo. Jakarta. 